\title{
Bronchoscopic spray cryotherapy: Assessment of safety and depth of airway injury
}

\author{
William S. Krimsky, MD, ${ }^{\mathrm{a}}$ Jennifer N. Broussard, MD, ${ }^{\mathrm{b}}$ Saiyad A. Sarkar, MD, ${ }^{\text {a }}$ and Daniel P. Harley, MD, ${ }^{\mathrm{c}}$ \\ Baltimore, Md
}

Traditional approaches to managing occluded airways include surgery, mechanical debulking, brachytherapy, stents, photodynamic therapy, and thermal modalities, such as electrocautery, laser, argon plasma coagulation, and cryotherapy. Although cryotherapy with cryoprobes has been used safely for over a decade in airways management, it is often tedious and time-consuming because of surface area limitations of the probes, which must be inserted into or come in contact with the surface of the targeted lesion. Newer cryotherapy devices obviate the need for contact with the target tissue. Reports of promising results from use of low-pressure spray cryotherapy for ablation of esophageal lesions ${ }^{1-2}$ have led to the experience reported here, in which spray cryotherapy with low-pressure liquid nitrogen was used for the first time to treat human airways.

\section{CLINICAL SUMMARY}

After provision of informed consent, spray cryotherapy with liquid nitrogen was performed on 21 subjects (Table 1) with the CryoSpray Ablation System (CSA Medical, Inc, Baltimore, Md) during standard bronchoscopy in anticipation of lung resection. Subjects were placed on $100 \%$ oxygen and ventilation through an endotracheal tube for maximal subject airway control in accordance with institutional guidelines. A 7F cryocatheter was introduced through the working channel of a therapeutic flexible, videobronchoscope (Olympus BFX1T160 or BF-X1T180; Olympus America Inc, Center Valley, $\mathrm{Pa}$ ) and extended $1 \mathrm{~cm}$ beyond the tip. A permanent dye marker (GIS-44; GI Supply, Camp Hill, Pa) was injected proximal to the intended treatment area at the takeoff of the segmental or lobar bronchus being treated to demarcate the treatment site. All sites received a targeted delivery of lowpressure (2-3 psi) liquid nitrogen of identical dosimetry, 2 cycles of 5-second spray with a 60-second interim thaw. Oxygen saturation and peak airway pressure were monitored con-

\footnotetext{
From the Pulmonary and Critical Care Department, ${ }^{\mathrm{a}}$ Surgical Pathology, ${ }^{\mathrm{b}}$ and the Thoracic Surgery Department, ${ }^{\mathrm{c}}$ Franklin Square Hospital Center, Baltimore, Md. Disclosures: CSA Medical, Inc, Baltimore, Md, loaned its CryoSpray Ablation System to the institution for use during this study.

Received for publication Nov 18, 2008; accepted for publication March 29, 2009; available ahead of print Aug 7, 2009.

Address for reprints: William S. Krimsky, MD, Pulmonary and Critical Care Department, Franklin Square Hospital Center, 9000 Franklin Square Dr, Baltimore, MD 21237 (E-mail: william.krimsky@medstar.net).

J Thorac Cardiovasc Surg 2010;139:781-2

$0022-5223 / \$ 36.00$

Copyright $(c) 2010$ by The American Association for Thoracic Surgery

doi:10.1016/j.jtcvs.2009.03.051
}

TABLE 1. Study subject demographics (treated $n=21$, resected $n=15$ )

\begin{tabular}{|c|c|}
\hline Age (y, mean and range) & $61.3(38-82)$ \\
\hline Female (no.) & $10(47.6 \%)$ \\
\hline \multicolumn{2}{|l|}{$\begin{array}{l}\text { Time from cryotherapy to resection } \\
\text { (no., actual with intent to resect) }\end{array}$} \\
\hline$<1 \mathrm{~d}$ & $5(6)$ \\
\hline $1-3 \mathrm{~d}$ & $2(3)$ \\
\hline $5-7 \mathrm{~d}$ & $3(5)$ \\
\hline $8-106 \mathrm{~d}$ & $5(7)$ \\
\hline \multicolumn{2}{|l|}{ Diagnosis for resection (no.) } \\
\hline Non-small cell lung cancer & $18(85.7 \%)$ \\
\hline Small cell lung cancer & $1(4.8 \%)$ \\
\hline Carcinoid tumor & $1(4.8 \%)$ \\
\hline Recurrent mycobacterial infection & $1(4.8 \%)$ \\
\hline \multicolumn{2}{|l|}{ Other diagnoses } \\
\hline Chronic obstructive pulmonary disease & 8 \\
\hline Asthma & 6 \\
\hline Chronic bronchitis & 2 \\
\hline Recurrent bronchitis & 2 \\
\hline Bronchiectasis & 2 \\
\hline Diabetes & 2 \\
\hline Coronary artery disease & 3 \\
\hline Heart disease & 1 \\
\hline History of myocardial infarction & 1 \\
\hline Hepatitis C & 2 \\
\hline Esophageal cancer & 1 \\
\hline Laryngeal cancer & 1 \\
\hline Breast cancer & 1 \\
\hline Hypertension & 1 \\
\hline Poliomyelitis & 1 \\
\hline Peripheral neuropathy & 1 \\
\hline Rheumatoid arthritis & 1 \\
\hline Anxiety or depression & 1 \\
\hline
\end{tabular}

stantly. All patients had treatment times shorter than 5 minutes. Bronchoscopic and histologic examinations of airways were conducted at various times, ranging from less than 1 day to 106 days after treatment. Postprocedural pain scores were assessed with a visual analog scale 24 hours after the procedure and 1 day before the scheduled resection.

Six of the 21 patients did not undergo surgical resection because of intraoperative findings. Histologic inspection of the resected specimens was performed at $250-\mu \mathrm{m}$ intervals by two pathologists (J.N.B.) blinded to specimen origin. They noted the number of slides showing any changes and where applicable the percentage of airway smooth muscle that was affected (Table 2). Findings from the treated areas revealed varying levels of cryonecrosis, limited to the mucosal and 
TABLE 2. Main histologic findings in sections of treated airway tissue

Other observed changes

\begin{tabular}{|c|c|c|c|c|c|c|c|}
\hline \multirow[b]{2}{*}{$\begin{array}{l}\text { Time to } \\
\text { resection }\end{array}$} & \multirow[b]{2}{*}{$\begin{array}{c}\text { Total } \\
\text { sections }\end{array}$} & \multirow[b]{2}{*}{$\begin{array}{c}\text { Airway } \\
\text { sections with } \\
\text { changes } \\
\end{array}$} & \\
\hline & & & $\begin{array}{c}\text { Altered } \\
\text { CASM }\end{array}$ & Epithelium & $\begin{array}{c}\text { Submucosal } \\
\text { glands }\end{array}$ & Cartilage & Parenchyma \\
\hline$<1 \mathrm{~d}$ & 25 & $18(72 \%)$ & $18 \%-64 \%$ & $\begin{array}{l}\text { Extensive sloughing } \\
\text { (16 sections), focal } \\
\text { sloughing ( } 2 \text { sections })\end{array}$ & $\begin{array}{l}\text { Recent injury ( } 9 \text { sections), } \\
\text { minimal regenerative } \\
\text { changes ( } 9 \text { sections) }\end{array}$ & $\begin{array}{l}\text { No significant change } \\
\text { ( } 25 \text { sections) }\end{array}$ & $\begin{array}{l}\text { No significant change } \\
\quad(25 \text { sections })\end{array}$ \\
\hline $2 \mathrm{~d}$ & 12 & $10(83 \%)$ & $5 \%-60 \%$ & $\begin{array}{l}\text { Sloughing (10 sections), } \\
\text { regenerative changes } \\
\text { (10 sections), } \\
\text { squamous metaplasia } \\
\text { (4 sections) }\end{array}$ & $\begin{array}{l}\text { Moderate regenerative } \\
\text { changes (10 sections) }\end{array}$ & $\begin{array}{l}\text { No significant change } \\
\quad(12 \text { sections })\end{array}$ & $\begin{array}{l}\text { No significant change } \\
\quad(12 \text { sections })\end{array}$ \\
\hline $6.3 \mathrm{~d}$ & 20 & $11(55 \%)$ & $33 \%-56.7 \%$ & $\begin{array}{l}\text { Sloughing (11 sections), } \\
\text { squamous metaplasia } \\
\text { (11 sections), regenerative } \\
\text { changes ( } 1 \text { section), } \\
\text { appearance of normal } \\
\text { (10 sections) }\end{array}$ & $\begin{array}{l}\text { Mild (4 sections) to } \\
\text { moderate (6 sections) } \\
\text { regenerative changes }\end{array}$ & $\begin{array}{l}\text { No significant change } \\
\text { (20 sections) }\end{array}$ & $\begin{array}{l}\text { No significant change } \\
\text { (20 sections) }\end{array}$ \\
\hline $37 \mathrm{~d}$ & 31 & $25(81 \%)$ & $5 \%-27.5 \%$ & $\begin{array}{l}\text { Sloughing ( } 8 \text { sections), } \\
\text { regenerative changes } \\
\text { (14 sections), squamous } \\
\text { metaplasia ( } 2 \text { sections), } \\
\text { normal epithelium } \\
\text { (23 sections) }\end{array}$ & $\begin{array}{l}\text { Mild (6 sections) } \\
\text { to extensive ( } 8 \text { sections) } \\
\text { regenerative changes, } \\
\text { return to normal } \\
\text { (11 sections) }\end{array}$ & $\begin{array}{l}\text { No significant change } \\
\text { (31 sections) }\end{array}$ & $\begin{array}{l}\text { No significant change } \\
\text { (31 sections) }\end{array}$ \\
\hline
\end{tabular}

Groups are according to mean time between cryotherapy and resection. Histologic assessments on serial sections are reported for each group. Because of tissue heterogeneity, sections were deemed positive for findings noted anywhere on section and are described as mild, moderate, extensive, or no significant change where possible. Ranges shown are means of ranges determined for each group of subjects. CASM, Circumferential airway smooth muscle (showing any change).

submucosal layers (approximately $1.5 \mathrm{~mm}$ ), and changes consistent with recent tissue injury with no damage to connective tissue. Loss of epithelium and airway smooth muscle, edema, and damaged submucosal glands observed at early time points were followed by adjacent re-epithelialization and healing centrally from the margin of the injury. Complete re-epithelialization of the airway mucosa and a thinned or absent smooth muscle layer, as well as some continued thinning of the submucosal glands, were persistent to 106 days after treatment.

Neither any adverse events nor any unanticipated side effects occurred with any of the procedures. No exacerbations were recorded for subjects with comorbidities such as asthma or chronic bronchitis. The mean pain score, as reported according to a visual analog scale of 0 to 10 , was 2.9. There was no evidence of scarring, and bronchoscopic evaluation 12 months after treatment of 3 patients who did not undergo resection was unremarkable.

\section{DISCUSSION}

This report demonstrates the safety and feasibility of applying spray cryotherapy in the human airway. Unlike the cryoprobe $\left(-86^{\circ} \mathrm{C}\right)$, spray cryotherapy with liquid nitrogen $\left(-196^{\circ} \mathrm{C}\right)$ is a noncontact method of tissue ablation, can be used to treat larger areas quickly, and provides more uniform treatment. This choice of cryogen and method of delivery creates an almost instantaneous freezing of the target tissue, which may result in greater depth and more complete cellular injury. ${ }^{3}$ The lack of uniform contact with the cryoprobe and the varia- tions in the isotherms as distance from the cryoprobe increases lead to incomplete tissue injury, which may pose problems. ${ }^{4-5}$

Recent reports of spray cryotherapy to treat Barrett esophagus, dysplasia, and esophageal cancers ${ }^{1-2}$ are promising. The mucosal epithelium of treated esophageal tissue regenerates without scarring, similar to our results in the airways. Our initial safety and histologic assessments suggest that spray cryotherapy may be safe and conducive to treatment of airway obstructions by causing focal injury to the cellular elements of treated tissue without damage to underlying connective tissue. Although the study included only a small number of subjects and normal, unobstructed airways were treated, regeneration of histologically normal epithelium, with the evident loss or thinning of airway smooth muscle and a decrease in the glandular content of the mucosa, suggest treatment possibilities in other human thoracic diseases.

\section{References}

1. Johnston MH. Cryotherapy and other newer techniques. Gastrointest Endosc Clin North Am. 2003;13:491-501.

2. Johnston MH, Easton JA, Horwhat JD, Cartledge J, Mathews JS, Foggy JR. Cryoablation of Barrett's esophagus: a pilot study. Gastrointest Endosc. 2005;62:842-8.

3. Baust JG, Gage AA. Progress toward optimization of cryosurgery. Technol Cancer Res Treat. 2004;3:95-101.

4. Pfleiderer SO, Freesmeyer MG, Marx C, Kühne-Heid R, Schneider A, Kaiser WA. Cryotherapy of breast cancer under ultrasound guidance: initial results and limitations. Eur Radiol. 2002;12:3009-14.

5. Roubidoux MA, Sabel MS, Bailey JE, Kleer CG, Klein KA, Helvie MA. Small $(<2.0-\mathrm{cm})$ breast cancers: mammographic and US findings at US-guided cryoablation-initial experience. Radiology. 2004;233:857-67. 